\title{
The Chinese Communist Party and People's Courts: Judicial Dependence in China
}

Forthcoming in the American Journal of Comparative Law Vol. 64, No.1, 2016

\author{
Ling LI
}

Author's note: Ling LI is a senior research scholar at the US-Asia Law Institute of New York University and an associate professor at the Northwest University of Politics and Law in China. She is the author of Performing "Bribery" in China - Guanxi-practice, corruption with a human face, The "Production" of Corruption in China's Court and The Rise of the Party Committee of Discipline and Inspection (1927-2012). She wishes to thank Jerome A Cohen, Ira Belkin, Stephanie Balme and Jake Clark who have read various versions of the draft of this article and provided valuable comments and suggestions. She can be reached at [LILING6234@GMAIL.COM]. 
Over the last decade, a growing amount of literature has enlightened us to an unprecedented level about the operation of the judicial system in contemporary China. Thanks to this valuable pool of literature, we witnessed that China's courts had evolved from a stern sanction unit of the Chinese Communist Party (hereinafter CCP or "party" unless qualified and indicated otherwise) specialized in meting out "revolutionary justice" against "enemies of the people"1 to a complex institution that is not just responsible for maintaining political monopoly of the party when adjudicating cases of political significance but is also endowed with authority to process and resolve an overwhelmingly large volume of non-political disputes that dominate the day-to-day court affairs. ${ }^{2}$ Unlike those pioneering scholars in the field, who had to rely on dispiriting accounts from political refugees ${ }^{3}$ or on evidence from unfortunate personal experiences to inform them about practices in these courts, ${ }^{4}$ today's researchers can conduct surveys and interviews among almost every category of court-users and even observe court activities live, either the rather dull trial procedure in courtrooms or the more engaging mediation in judges' offices as the events transpire. ${ }^{5}$ Some contemporary researchers even enjoyed privileged access to classified court dossiers including minutes of judges' deliberation meetings held in court backrooms that are closed not only to ordinary observers but also to litigants. ${ }^{6}$

As a result, our knowledge about China's courts has expanded significantly both in scope and depth over a short time span. It covers a wide range of topics from court decision-making bodies, ${ }^{7}$ court mediation, ${ }^{8}$ court personnel ${ }^{9}$ and personnel management ${ }^{10}$, court finances, ${ }^{11}$ to judicial authority ${ }^{12}$ or the lack of $i^{13}$

\footnotetext{
${ }^{1}$ Henry McAleavy, The People's Courts in Communist China, AM. J. Comp. L. 52 (1962). Jerome Alan Cohen, The Party and the Courts: 1949-1959, 38 THE CHINA QUARTERLY 120 (1969).

2 Yulin Fu, Randall Peerenboom, A New Analytical framework for understanding and promoting judicial independence in China, in JUdicial INDEPENDENCE IN CHINA: LeSSONS FOR GLOBAL RULE OF LAW PROMOtION 96 (Randall Peerenboom ed. 2010).

${ }^{3}$ See Cohen, supra note 1 at 137-152.

${ }^{4}$ See McAleavy, supra note 1, at 62-64.

5 Jialiang Huang, Logic of law in operation in lower courts in China [Falü zai jiceng fayuan zhong de shijian luoji], in SELECTED

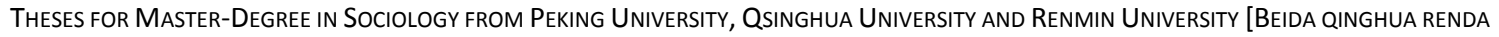
SHEHUIXUE SHUOSHI LUNWEN XUANBIAN] 1-20 (Yefu Zheng, et.al. ed. 2006).

${ }^{6}$ Xin He, Black Hole of Responsibility: The Adjudication Committee's Role in the Chinese Court, Law \& Soc'y Rev. 681 (2011). 7 /d.

${ }^{8}$ Philip C. C. Huang, Court Mediation in China, Past and Present, 32 Modern CHINA 275 (2006). Ng Kwai Hang \& HE Xin, Internal Contradictions of Judicial Mediation in China, 39 LAW \& SOC. INQUIRY 285 (2014).

${ }^{9}$ Donald Clarke, Empirical Research into the Chinese Judicial System, in BEYOND COMmon KNOWLEDGE: EMPIRICAL APPROACHES TO THE RULE OF LAW 164-192 (Erik Gilbert Jensen, Thomas C. Heller ed. 2005). Jerome A. Cohen, Reforming China's Civil Procedure: Judging the Courts, 45 The American Journal of Comparative LaW 793 (1997). Stéphanie Balme, Local Courts in Western China: The Quest for Independence and Dignity, in JUDICIAL INDEPENDENCE IN CHINA: LESSONS FOR GLOBAL RULE OF LAW PROMOTION 154-179 (Randy Peerenboom ed. 2010). Stanley Lubman, Bird in a Cage: Legal Reform in China after Mao Ch. 9 (1999) Benjamin L. Liebman, China's Courts: Restricted Reform, 191 THE CHINA QUARTERLY 620 (2007).

${ }^{10}$ Carl Minzner, China's Turn Against Law, 59 Am. J. Comp. L. 935 (2011).

${ }^{11}$ Xin He, Court Finance and Court Responses to Judicial Reforms: A Tale of Two Chinese Courts, 31 LAW \& PoL'Y 463 (2009). Yuhua Wang, Court Funding and Judicial Corruption in China, 69 THE CHINA JOURNAL 43 (2013).

12 Young Nam Cho, Symbiotic Neighbour or Extra-Court Judge? The Supervision over Courts by Chinese Local People's Congresses, 176 The China QuARTERLy 1068 (2003). Benjamin L. Liebman, The Media and the Courts: Towards Competitive Supervision?, 208 THE CHINA QUARTERLY 833 (2011).

${ }^{13}$ Randall Peerenboom, China's Long March toward the Rule of Law (2002) Xuehua ET. AL. Zhang, Agency Empowerment through the Administrative Litigation Law: Court Enforcement of Pollution Levies in Hubei Province, 202 THE CHINA QUARTERLY 307 (2010). Xin He, The Judiciary Pushes back - Law, power and politics in Chinese courts, in JUDICIAL INDEPENDENCE IN CHINA: LESSONS FOR GLOBAL RULE OF LAW PROMOTION 180-195 (Randy Peerenboom ed. 2010). Donald Clark, Power and Politics in the Chinese Court System: The Enforcement of Civil Judgments, 10 CoLUM. J. AsIAN L. 1 (1996). Also see Balme, supra note 9.
} 
and even encompassing the problem of judicial corruption. ${ }^{14}$ What is missing from this growing volume of literature is presumably one of the most prominent topics: the role of the Chinese Communist Party in courts. The reason for the "presumed prominence" of this topic resides in the understanding that the relationship between the party and the courts determines whether courts are independent, a quality so central to our knowledge of proper court performance that the absence of it is considered as a default cause for flaws or injustice unless these can be proved otherwise. Surprisingly, the volume of research dedicated to this subject is disproportionately small. Perhaps the reason is that the subject is not "legal" enough for lawyers and not "political" enough for political scientists. This lack of attention given to this subject only makes Jerome A. Cohen's seminal work of 1969 even more conspicuous.

Professor Jerome A. Cohen's article on "The Chinese Communist Party and Judicial Independence (19491959)" was first published in 1969 in the Harvard Law Review, ${ }^{15}$ and later appeared in The China Quarterly under the title of "The Party and the Courts (1949-1959)". At the time of Cohen's study, the Chinese state was not fully integrated, the national judicial system was, incomplete at best, laws were scant, and a large proportion of judges were drawn from the ranks of military veterans and political activists. Being sympathetic to China's situation, Cohen started his investigation by expressing skepticism about the universality of the value of judicial independence. Considering "judicial independence" a matter of relative value, he warned readers that "each country's political-judicial accommodation must be located along a spectrum that only in theory ranges from a completely unfettered judiciary to one that is completely subservient."16 Through a chronological account of the development of the party-court relations from 1949 to 1956, Cohen found that the party dominated the judiciary because neither the political or economic costs of this domination were perceived "as remotely approaching the very substantial benefits it could yield". ${ }^{17}$ Recognizing that the authoritarian historical "heritage" may constitute a great obstacle for judicial independence to take root in China, ${ }^{18}$ Cohen, nevertheless, maintained an admirable level of optimism that few in the West then shared. He ended his study with a wistful conclusion, expressing hope that "the party leaders may gradually acquire a deeper appreciation of the virtues of functional specialization, professionalization, and judicial autonomy than they displayed" when the party became more politically secure and economically developed. ${ }^{19}$

It took four decades before ZHU Suli, a prominent native Chinese law professor from the prestige Peking Law School, revisited and wrote on the subject of Cohen's article, with a notable sense of nostalgia of rural life in China. Unlike Cohen's intellectual curiosity, ZHU's choice of the subject of the party and the courts was due to intellectual "provocation" that he experienced when reading Professor Frank Upham's review of one of his most influential works: "Sending Laws to the Countryside: A Study of the Basic-Level Judicial System". In that review, Upham criticized that ZHU's investigative approach and romanticized

\footnotetext{
${ }^{14}$ Ling Li, Corruption in China's courts, in JudicIAL INDEPENDENCE IN CHINA: LeSSONS FOR GLOBAL RULE OF LAW PROMOtION 196-220 (Randall Peerenboom ed. 2010). Ling Li, The "Production" of Corruption in China's Courts - The politics of judicial decision-making and its consequences in a one-party state, 37 LAW \& SOC. INQUIRY 848 (2012). Keyuan Zou, Judicial reform versus judicial corruption: recent developments in China, 11 CRIMINAL LAW ForUm 321 (2000). Also see Wang, supra note 11.

${ }_{15}$ Jerome Alan Cohen, The Chinese Communist Party and "Judicial Independence": 1949-1959, 82 HARV. L. Rev. 967 (1969).

16 See Cohen, supra note 1 at 125 .

$17 / d$. at 156.

$18 / d$. at 152-157

${ }^{19} / d$. at 157.
} 
conclusion was flawed because his analysis did not factor in the party's influence. ${ }^{20} \mathrm{ZHU}$ responded with a rebuttal, published first in the Chinese language in $2006^{21}$ and turned into an English language article in 2010 under the title "The Party and the Courts". ${ }^{22}$ The rebuttal shares an uncanny resemblance to Cohen's as to his skepticism towards "Western standards" of judicial independence. Professor ZHU too asked, almost in identical terms, why China's courts should be measured against Western standards of judicial independence, standards that even Western courts could not invariably satisfy. ${ }^{23}$ But in contrast to Cohen's endeavor to clarifying the relation between the party and the courts, ZHU argued that the party's dominance over the Chinese state, including courts, is "inescapable" as a "historical process of China's modernization". ${ }^{24} \mathrm{He}$ also argued that such dominance is so pervasive and omnipresent that it renders any attempt to distinguish party activities from state activities impossible and unnecessary. ${ }^{25}$

In this article, I intend to renew the investigation of the relation between the party and the courts so as to examine how this relation has evolved, how to characterize the nature of this relation and how this relation has impacted on court activities. Despite the challenge posed by the complexity of this subject, this intellectual exercise is nonetheless both necessary and important because any sound appraisal of the effect of the party's influence over court activities needs to be built on a good understanding of what that influence is and how such influence is exercised. In Section I, my investigation begins by recapping the party's efforts to reinstitute courts soon after taking over the state from the Kuomintang Party (KMT). Section II traces the change of status of courts in the party-state structure since 1949 till the present time. Section III will chronologically lay out the vicissitudes of the evolution of specialized supervisory bodies of the party that have been put in charge of routine inspection of court activities. Section IV will detail the mechanisms through which the party manages its control of judicial activities thereby embedding courts in the overall political structure of the party-state. The article concludes in Section $\mathrm{V}$ with main findings based on the wealth of evidence shown in previous sections.

\section{I. "People's Courts": Court purgatory campaign}

Throughout Chinese imperial history, the judicial and executive functions of government were jointly exercised by magistrates in most parts of China. ${ }^{26}$ Specialization of the judicial function was practiced, of varied degrees, only at the national level. This situation remained intact until the early $20^{\text {th }}$ century. During Yuan Shikai's Beiyang Government, judicial reforms were pursued based on the principles of rule of law, judicial independence and due process, which had set out the trend of the modernization of the Chinese judicial system. ${ }^{27}$ When the KMT took power, it introduced the one-party political system, under

\footnotetext{
${ }^{20}$ F. K. Upham, Who Will Find the Defendant if He Stays with His Sheep? Justice in Rural China, 114 YALE L. J. 1675, 1717 (2005)

${ }^{21}$ Suli Zhu, Zhongguo sifa zhong de zhengdang [Political Party in Chinese Justice System], 1 FALV YU SHEHUI KEXUE [LAW AND SOCIAL SCIENCE] 256 (2006)

22 Suli Zhu, The Party and The Courts, in JUdiCIAL INDEPENDENCE IN CHINA: LeSSONS FOR GLOBAL RULE OF LAW PROMOTION 52-68 (Randall Peerenboom ed. 2010).

${ }^{23}$ Cohen, supra note 1 at 125-128, 154; Zhu, supra note 21 at 267-272.

${ }^{24} \mathrm{Zhu}$, supra note 22 at 64 .

25 Zhu, supra note 21 at259-267.

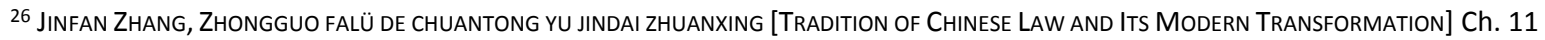
(1997) Also see Tongzu Qu, Local gOVERnMENT In CHINA UNDER THE CH’ING 14-35 (1962).

27 XIAOQUN XU, TRIAL OF MODERNITY: JUdiCIAL REFORM IN EARLY TWENTIETH-CENTURY CHINA 1901-1937 Ch. 2 (2008)
} 
which the Nanjing National Government (National Government) was established. Since the KMT considered its one-party rule as a makeshift arrangement for the transition to the electoral constitutional government, ${ }^{28}$ it continued the judicial reforms started in the Beiyang era and preserved the principles of rule of law, judicial independence and due process, ${ }^{29}$ despite significant limitations of these reforms due to the political constraints of the one-party rule. ${ }^{30}$

Concurrently, in the party-controlled "border regions", ${ }^{31}$ court-like institutions were also established to provide resolution for civil disputes and, more importantly, conduct criminal trials. Unlike courts in the KMT-controlled areas, these courts were not separate from the executive branch and were considered the latter's divisional subordinates. ${ }^{32}$ The administrative body could issue law and directly instruct courts in criminal prosecution and sentencing. ${ }^{33}$ In the late 1940s when power shifted its balance between the two political parties, the party started to prepare for the ultimate military takeover from the KMT, including the takeover of the state legal system that was installed by the KMT's National Government.

In February 1949, the party issued an instruction (known as the "February Instruction") to abolish all six legal codes that were promulgated by the National Government and replace them with party policies and various decisions issued by the party in the names of People's Government and the People's Liberation Army. ${ }^{34}$ In 1950, the State Council of the newly established People's Republic of China (P.R.C.) announced that courts were an important instrument to safeguard "people's power", the same as the army and the police ${ }^{35}$ It also urged judges and court officials to have a clean break from old laws and perceptions. ${ }^{36}$ Following the issuance of the February Instruction, the State Council Political-Legal Committee held a meeting and called for a campaign that combined thought reform and institutional

\footnotetext{
${ }^{28} \mathrm{Xu}$, supra note 27 at $\mathrm{Ch} .2$.

${ }^{29}$ Id. at Ch. 2. Liangcai Ji, Nanjing guomin zhengfu sifayuan zhineng bianqian ji tezheng fenxi [An Analysis of the Changes and Features of the Functions of the Judicial Yuan of the Nanjing National Government] 30 FAZHI YU SHEHUI [RULE BY LAW AND SOCIETY] (2008). Haiyan Zhou, Nanjing guomin zhengfu sifayuan yanjiu [A Study of the Sifayuan of Nanjing National Government], Master MASTER Thesis (JIANGXI NORMAL UnIVERSITY) (2008). Xu, supra note 27 at Ch. 3. Boying Zhuo, wuquan xianfa zhidu yanjiu [A Study on the Five-Power Constitutional Government], Doctoral Doctoral THeSIS (TAIWAN CHINESE CULTURE UNIVERSITY) (1980).

${ }^{30}$ Jinwen Xia, Qin Ce, minguo shiqi sifa duli de maodun fenxi [An Dialectic Analysis of Judicial Independence in Minguo Period], 5 NANIING UNIVERSITY SOCIAL SCIENCE JOURNAL 52 (1999). RenSHAN ZHANG, SIFA FUbAI YU SHEHUI SHIKONG (1928-1949) [JUdICIAL CORRUPTION AND THE LOSING OF SOCIAL CONTROL (1928-1949)] (2005)

${ }^{31}$ Border-regions refer to a few pockets of land located in remote territories the borders of which were shared by adjacent provinces. The party set base in these regions because they were more secure, being far away from KMT's political centers and attention.

32 SHIRONG WANG, XIN ZHONGGUO SIFA ZHIDU DE JISHI: SHAN'GANNING BIANQU GAODENG FAYUAN (1937-1949) [THE FUNDATION OF THE JUDICIAL System of the new China: Shan'ganning Border Region High Court (1937-1949)] (2011)

${ }^{33}$ Xiuling Wei, Shan'ganning bianqu shuishou falv zhidu de chansheng ji jiben yuanze [The Emergence and Basic Principles of the Taxation Legal System in Shan'ganning Border Region], 6 ZHengfa LUNTAN [PoLITICAL-LEGAL ForUM] 117 (2001). Jianfu Yang, Zhang Yongliang, Shan'ganning bianqu hunyin jiating falv zhidu de lishi diwei [Historical Status of the Marrige and Family Law in Shan'ganning Border Region], 2 Longdong College SocIAL SCIENCE JouRnal 67 (2003). Xinyi Hou, Shan'ganning bianqu gaodeng fayuan sifa zhidu gaige yanjiu [A Study on the Judicial Institutional Reforms in Shan'ganning Border Region High Court] FAXUE yanju [Legal Studies] 129 (2004).

${ }^{34}$ Central Party, Guanyu feichu guomindang liufa quanshu yu queding jiefangqu de sifa yuanze de zhishi [Party Instruction Regarding the Abolition of the Six Codes of the KMT and the Establishment of Judicial Principles in Liberated Area] (1949). ${ }^{35}$ State Council, Zhengwuyuan guanyu jiaqiang renmin sifa gongzuo de zhishi [Instruction on Enhancing People's Judicial Work] (1950).

$36 / d$.
} 
rectification, to "purify" judicial institutions politically, institutionally and ideologically. ${ }^{37} \mathrm{~A}$ detailed campaign proposal was submitted by the Minister of Justice Shi Liang to the State Council, the objectives of which were: 1) to repudiate the "old" laws and 2) to reform the "old" judicial staff in order to purify and completely rebuild the judiciary. ${ }^{38}$ The identified "old" laws and ideas included: judicial independence, the equality of law, the supremacy of legal procedure, the usefulness of the "old" law, and the apolitical nature of law. ${ }^{39}$

The State Council approved the proposal and the campaign was launched in courts nationwide between 1952 and $1953 .{ }^{40}$ During the campaign, masses were mobilized in a "measured" and "planned" fashion to report and expose "anti-revolutionary" court decisions or practices. ${ }^{41}$ "Mass line" was systematically introduced to courts. ${ }^{42}$ People's assessors were invited to participate in the adjudication and people's tribunals were established in villages and urban communities for the convenience of residents. ${ }^{43}$ "Cold cases" were dealt with expediency upon people's demand. ${ }^{44}$ University law departments were repurposed for the training of political-legal cadres. ${ }^{45}$ "Unsuitable" law teachers were either expelled from universities or reallocated to teach other courses. ${ }^{46}$ Purification of judicial officials was achieved through criticism and self-criticism, which was made mandatory for judges and judicial staff in study sessions ${ }^{47} \mathrm{~A}$ great number of judges and judicial officials who were "taken over" from the National Government were re-vetted and some were subsequently expelled. ${ }^{48}$ To fill their vacancies, the party dispatched trusted senior cadres to take those executive positions in courts. For the non-executive posts, the party filled them with military veterans, workers, union cadres, young intellectuals and the rank and file, who had distinguished themselves with excellent performance in the party's political campaigns and were considered politically loyal and enthusiastic. ${ }^{49}$

Through the judicial reform campaign, the party transformed court institutional structure, ideology and work-style. "Old" courts became "people's courts", which could then be entrusted with constitutional

\footnotetext{
37 Jianguo chuqi de sifa gaige yundong [The Judicial Reform Campaign in the Early Period of the P.R.C.], in DANGDAI ZHONGGUO DE

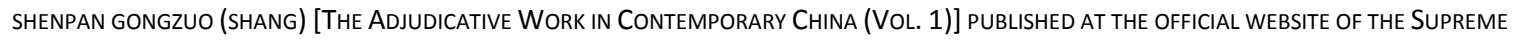
PeOPLE'S COURT, AVAILABLE AT HTTP://WWW.CHINACOURT.ORG/ARTICLE/DETAIL/2009/03/ID/347417.SHTML (HE Lanjie ed. 1993).

${ }^{38}$ Guangzhong Chen, Zeng Xinhua, Jiangui chuqi sifa gaige yundong shuping [A Commentary Narrative about the Judicial Reform in Early Period of the P.R.C.], 6 FA XUE JIA 1 (2009). DONG Jieying, 1952 nian beijingshi de sifa gaige yundong [The Judicial Reform Campaign in Beijing in 1952], 2 BEIING DANGSHI [BEIING PARTY HISTORY] 21 (2007). Guanyu jinxing sifa gaige ying zhuyi de jige wenti de zhixing [Instruction about a few issues calling for attention regarding the implementation of the judicial reform] issued by the Central Party in 1952.

${ }^{39}$ Qinliang Ding, Jianguo chuqi de sifa gaige yundong yanjiu [A Research on the Judicial Reform Campaign during the Early Period of the P.R.C.], MASTER THESIS OF ANHUI UNIVERSITY, 74-78 (2013).

$40 / d$.

41 ld.

42 See Chen, supra note 38 at 1-6. Site Li, renmin sifa qunzhong luxian de puxi [The Geneaology of People's Judicial Mass Line ], 1 FALV HE SHEHUI KEXUE [LAW AND SOCIAL SCIENCE] 285-316 (2005).

${ }^{43}$ See Chen, supra note 38 at 1-6.

${ }^{44}$ See Ding, supra note 38 at $70-80$.

${ }^{45}$ See Chen, supra note 38 at 1-6.

${ }^{46} / d$. Also see Ding, supra note 38 at $70-80$.

${ }^{47}$ Guanyu jinxing sifa gaige ying zhuyi de jige wenti de zhixing [Instruction about a few issues calling for attention regarding the implementation of the judicial reform] issued by the Central Party in 1952.

${ }^{48}$ See Chen, supra note 38 at 1-6. Also see Ding, supra note 38 at 70-80.

49 Id. Chen, at 3.
} 
status as a specialized institution to "help enforce party policies, consolidate the people's dictatorship, and decide disputes through application of the law".$^{50}$ Towards the end of the reform, the Party-Group of the Political-Legal Committee of the State Council proposed to the Central Party Committee that all party committees should strengthen their supervision and inspection over the performance of courts and that a standing party committee member should be designated to oversee judicial affairs. It also proposed that leaders of all judicial institutions should proactively and timely submit reports to party committees and strictly follow the request-for-instruction-and-report rule. ${ }^{\prime 51}$ The party approved this proposal and circulated it to all party institutions for implementation..$^{52}$ Meanwhile, the party had quickly established its outposts, in forms of party committees and/or party-groups in courts, procuratorates and other political-legal institutions. ${ }^{53}$ These party-groups became and have remained as the critical node that links the party and the judicial and legal institutions which they simultaneously serve.

\section{Courts in the party-state}

When the party took over power from the KMT in 1949, it introduced the Common Program (gongtong gangling) as a transitional constitution. According to the Common Program, which has strong Soviet influence, the state power resided in the Central (coalition) Government, members of which were to be elected by the National People's Congress (see Figure 1).${ }^{54}$ Once elected, the Central Government would become the highest state decision making body, ${ }^{55}$ resembling a national legislature. Under the Central Government were the executive branch, i.e. State Council, the Supreme People's Court (SPC) and the Supreme People's Procuratorate (SPP). ${ }^{56}$ In practice, since the Central Government was only an assembly with no implementation and enforcement facilities and resources, it had to delegate most of its decision-making power to the State Council. At the same time, the State Council was also mandated to manage the SPC and the SPP through its Political-Legal Committee on behalf of the Central Government via personal instructions from Mao Zedong, the Chairman of the Central Government, and Zhou Enlai, the premier of the State Council, ${ }^{57}$ despite that constitutionally courts were established as a state institution separate from the State Council. This means that in the earlier years of the P.R.C., since the power of the Central Government remained mostly nominal, the State Council exercised the executive, judicial, prosecutorial and, to some extent, legislative power.

\footnotetext{
50 Fengjing Liu, "Daobazi" de yinyuxue chanshi - fenxi renmin fayuan xingzhi yu zhineng de xin jinlu [The Implicit Metaphoric Interpretation of "Knife Handle" - A New Approach to Analyzing the Nature and Function of People's Courts, 2 TsingHUA LAW REVIEW (2008).

51 Zhen Peng, Lun xin zhongguo de zhengfa gongzuo [On the Political-Legal Work in New China] 77 (1992)

52 See Ding, supra note 38 at 104.

53 Jinyan Zhong, Zhengfawei lishi yu yanbian de zai sikao [A Revisit to the History and Vicissitude of the Political-Legal Committee], yanhuang CHunqIU [CHINA through the Ages] 50 (2012).

${ }^{54}$ Igor I. Kavass, Christian Gary I., 1977 Soviet Constitution: A Historical Comparison, 12 VAND. J. TRANSNAT'L L. 533 (1979).

${ }^{55}$ Gongtong gangling [Common Program] promulgated by the Chinese People's Political Cosultance Conference on Sep. 29, 1949. art. 12.

${ }^{56}$ Zhongyang renmin zhengfu zuzhi fa [Organizational Law of the Central People's Government] (promulgated by the Chinese People's Political Cosultance Conference on Sep. 27, 1949) Available at http://www.cppcc.gov.cn/2011/09/06/ARTI1315304517625201.shtml. art. 15.

${ }^{57}$ Zhong LIU, The Shaping of the Thought of Party Governing Politics and Law in Organization History (1949-1958), 2 FA XUEJIA [THE JURISTS] 16, 5 (2013).
} 
Figure 1: $\quad$ Party-state structure (1949)

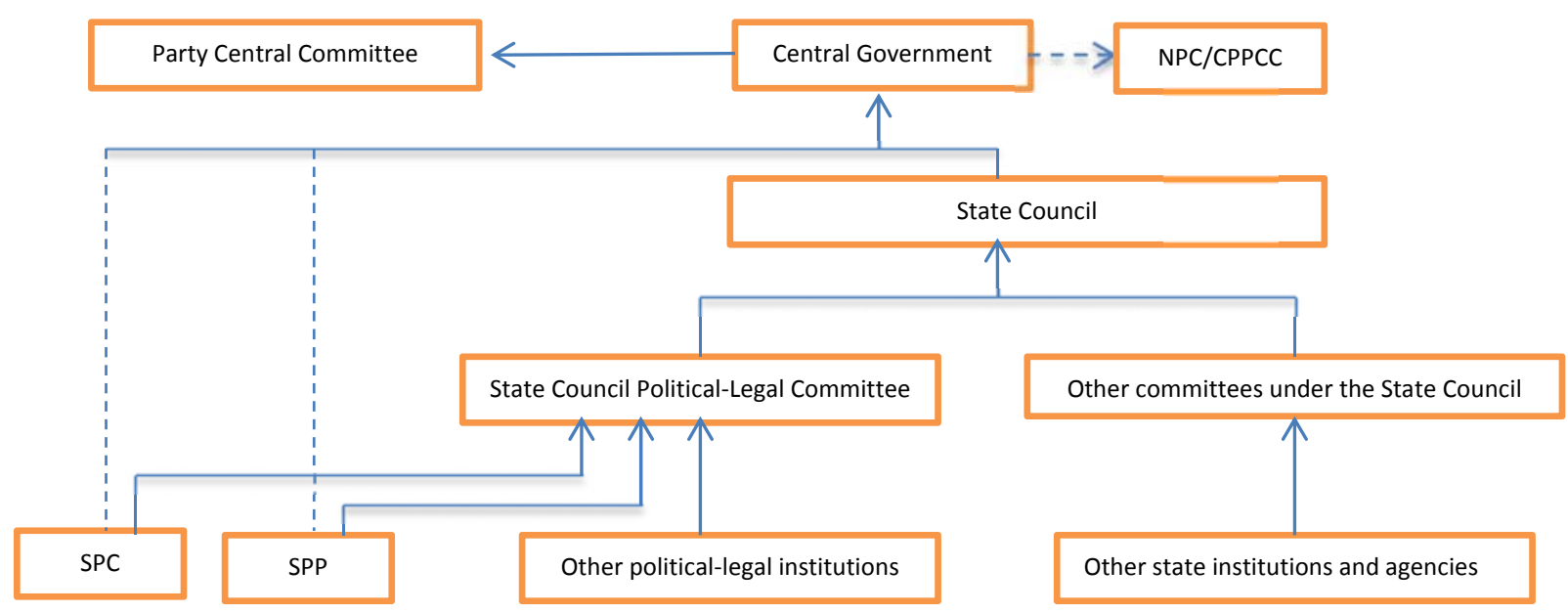

As shown in Figure 2, the state structure significantly augmented the power of the State Council and simultaneously slowed down, if not blocked, the information flow from various state institutions to the Central Party Committee, chaired by Mao. Mao considered such operation "bureaucratic" and having impaired his ability to oversee and control the development of important state affairs. ${ }^{58} \mathrm{~A}$ new constitution was drafted, under Mao's attentive supervision at the lakeside of Hangzhou City, ${ }^{59}$ and subsequently promulgated in 1954. The new constitution flattened the state structure. It dissolved the Central Government and separated state power among four branches: the legislature, the executive, the judiciary and the prosecution. At the same time, the Constitution (1954) also installed a measure of "supervised checks and balances" among the four branches of the state. The National People's Congress was the highest decision-making body of the state..$^{60} \mathrm{It}$ was to elect the head of government and to make laws. ${ }^{61}$ The State Council was to administer state affairs according to the law. ${ }^{62}$ Courts were to adjudicate disputes according to the law. ${ }^{63}$ The Procuratorate was to inspect any violation of laws by state institutions and individual citizens. ${ }^{64}$

\footnotetext{
58 /d. at 7, 10-11. 21.

61 Id. Art. 31.

62 Id. Art. 43, 47

63 ld. Art. 73.

${ }^{64}$ Id. Art. 81.
}

${ }^{59}$ Annoymous, Mao Zedong zhuchi zhonghua renmin gongheguo di yibu xianfa [Mao Zedong Taking the Lead to Draft the 1st Constitution of the P.R.C.] available at http://www.china.com.cn/chinese/zhuanti/qdxxlfchx/463953.htm, QIANLONG NEWS NETWORK, Oct. 22. 2003.

${ }^{60}$ Zhonghua renmin gongheguo xianfa [P.R.C. Constitution] promulgated by National People's Congress on Sep. 20, 1954. art. 


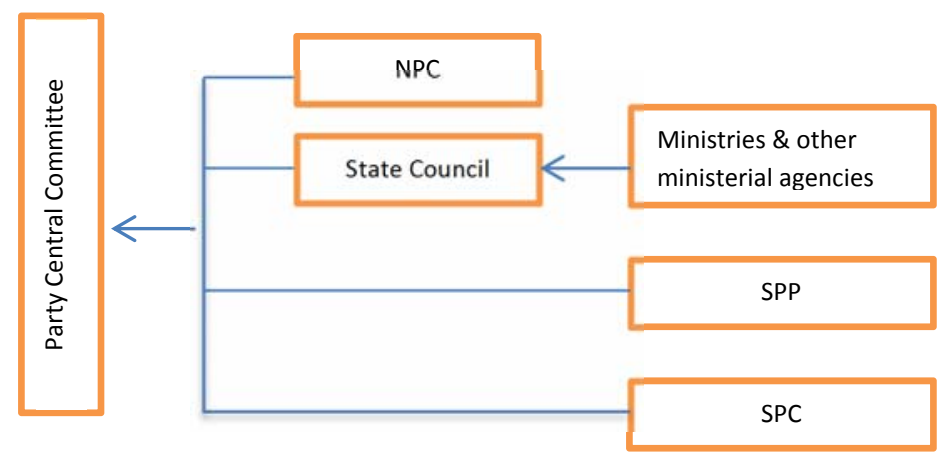

In Professor Cohen's 1969 article, what appeared to have baffled him most was the introduction of Article 78 to the Constitution (1954). Article 78 stipulated: "Courts exercise judicial power independently and only answer to the law". Cohen was perplexed by the unequivocal commitment to judicial independence pronounced in Article 78, a principle that the party was evidently not planning to uphold. Why would the party put it in the constitution then? Was it only about window-dressing? The chain of events, as described in previous paragraph, suggests two scenarios which may have led to the insertion of Article 78 in the constitution. The first scenario is that the party intended to separate the judicial function only from the executive branch and hence to "exercise judicial power independently" as indicated in Article 78 only referred to independence from the executive branch. The second scenario is that the drafters may have presumed that as long as the party controls law-making and the appointment of judges, to have courts answer to the law is the same as to have courts answer to the party. After all, at that time, the party had not had any experience with the administration of a modern legal system and hence could not full grasp what judicial independence would entail.

If Article 78 is indeed a slip of naiveté, the party had certainly become aware of it when the constitution was amended in 1982. In the amended constitution, Article 78 was replaced by Article 182, which stipulated: "Courts are to exercise judicial power independently and free from interference from the executive branch of the government, social organizations and individuals". By listing the institutions that courts shall be independent from, Article 182 acquiesced that the party, which is not listed, is entitled to "interfere" with judicial activities. At the same time, not surprisingly, the provision that "courts only answer to law" was deleted from the constitution.

Soon after the 1982 Amendment of the Constitution, the party also elevated the rank of courts by one grade (half of a level) through the "high-equipping (gao pei)" practice (see Figure 3). ${ }^{65}$ After the upgrade,

\footnotetext{
${ }^{65}$ To begin with, there are currently five grand rank-categories applied to public institutions, each category corresponding to one administrative level: national, provincial, prefectural, county and township. Each level of rank is further divided into two grades, chief and deputy, to accommodate finer categorization. Within each public institution, ranks are also allocated to divisions in a descending order. For example, the head of the State Council, i.e. the premier, enjoys the national-level rank, chief grade. Consequently, various ministers and heads of other second-tier divisions of the State Council, enjoy the rank of provincial-level, chief grade, and so on. The party had for a long time considered courts as a division of the executive branch. Therefore, courts were ranked one level lower than the executive branch that shares the same territorial jurisdiction. For example, the Supreme People's Court would have a provincial-rank, despite its jurisdiction covers the entire nation. This rank
} 
courts are half-grade above divisions of the executive branch, except those divisions that also benefited from the high-equipping practice, such as the public security bureaus. ${ }^{66}$

\section{Figure 3: $\quad$ Party-state structure (1982)}

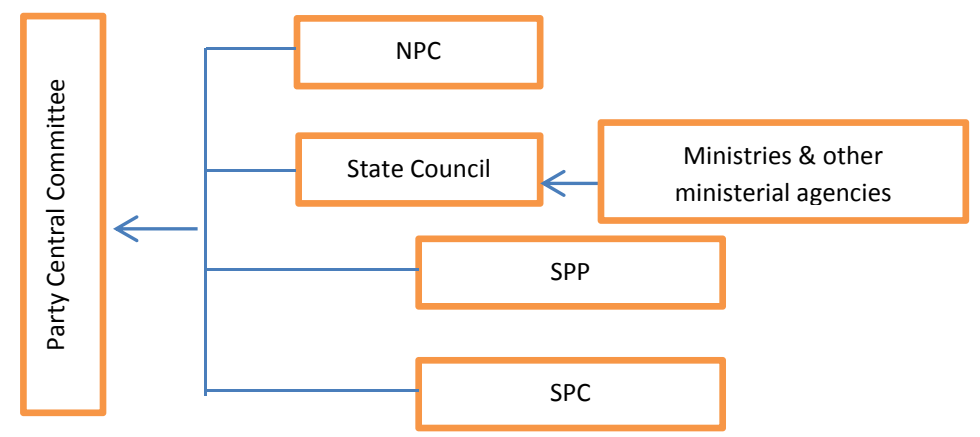

The combination of "judicial independence" and the supreme authority of the party over the state has many ramifications regarding the authority of China's courts. The first and also most evident is that courts cannot scrutinize activities of the party. Instead, party activities are subject to self-regulation from top-down. ${ }^{67}$ The second is that the capacity of a court to command compliance from a subject of court, either being an institution or individual, is constricted by the power relation between the court and that subject involved. The party determines and administers a rank order that embodies the chain of command, which is essential for the authoritarian rule of the party over the state. Every state institution is assigned a rank, including courts. The scope of authority of any given court over a subject is commensurate to that subject's rank vis a vis the court. In other words, courts can command compliance by institutions and individuals of lower or no rank but not by those of equal or higher ranks or those who can draw influence from the former, unless the party authorizes it. By subjecting courts to this rank order, the party can maintain its supreme authority over judicial authority. This relative nature of judicial power also explains why China's courts can be on the one hand too powerful, capable of

status of courts had not changed until in 1983 through a "high-equipping practice". "High-equipping" is a less costly approach to raise the rank status of an institution by upgrading only the rank of its leaders rather than that of the institution as a whole. It is because the impact of the rank of an institution is much more overreaching than that of individual posts within the institutions. For one thing, it would affect the rank of each single post within the institution as well as its associated benefits. To upgrade the rank of the leader of an institution, by contrast, only impacts the designated posts and hence is much less costly. Therefore, in 1983, when the party sent cadres to fill court posts, specific instructions were issued that court presidents should be ranked the deputy-grade of the level that matches their territorial jurisdictions. For example, a provincial high court president would be ranked provincial-level, deputy-grade. It means that a court president would be now half-level (one grade) lower than the head of the executive branch but simultaneously half-level (one grade) higher than the second-tier divisions or agencies of the executive branch. For commentaries of such practices, see, for example, Haoping Qian, tamen weihe guangao banji - ganbu gaopei de chuantong yu xianshi [Why are they half-rank higher? - Tradition and Reality of "gaopei"], XIN CHEN BAO (2014).

66 Yuhua Wang, Empowering the Police: How the Chinese Communist Party Manages Its Coercive Leaders, 219 THE CHINA QUARTERLY (2014).

${ }^{67}$ Zhongguo gongchandang dangzhang [Chinese Communist Party Charter] amended by the Chinese Communist Party in 2012. Chapter 2. 
corrupt and even predatory conduct, extracting resources from litigants with no political status or influence, ${ }^{68}$ and on the other hand completely deplete of power, shunning, as frequently seen, cases that are brought by litigants against powerful institutions and individuals. ${ }^{69}$

At the same time, the "judicial independence", or rather, the "judicial dependence" of courts upon the party makes the party's engagement in judicial affairs prominent for two reasons. First, the party, being the only institution that has authority over both courts and other state institutions, has acquired a privileged position that allows it to break the checks and balances and align actions of various state institutions for the purpose of implementation of prioritized party policies and decisions. Second, since courts cannot command compliance by institutions of equal or higher ranks, they have to frequently engage the party to provide solutions for disputes between courts and other such state institutions, as well as to marshal resources and command compliance by other state institutions so that courts can perform their judicial activities.

Frequent demands for the afore-mentioned actions had made it necessary for the party to establish specialized party apparatus to handle these issues on a routine basis. Next section will explain the institutional development of these specialized party apparatus, which is, however, not a linear process. As will be shown, these institutions had gone through cycles of disbandment, resurrection, reshuffling and became more stabilized only after 1990 .

\section{The Party political-legal apparatus}

In China, collective references of law-related institutions can be somewhat confusing. It is therefore necessary to first clarify relevant nomenclature that will appear below. In this article, I use the term "party political-legal apparatus" as a reference of specialized party institutions that are established to conduct routine supervision of the so-called "political-legal institutions". These "political-legal institutions (zhengfa jiguan)" refer to state institutions ${ }^{70}$ that perform law-related functions, typically including courts, the police, the procuratorates, the Ministry of Justice but not the legislature, i.e. people's congresses. ${ }^{71}$

The institutional development of party political-legal apparatus since 1949 has been a process of constant shifts, in terms of its names, structures and functions. As shown in Table 1, the first party political-legal apparatus was the Party-Group nested under the State Council Political-Legal Committee established in 1949 (see Figure 1). ${ }^{72}$ The mandate of the State Council Political-Legal Committee

\footnotetext{
68 See Li, supra note 12 in Law \& Soc. Inquiry.

${ }^{69}$ Xin He, Why Did They not Take the Disputes? Law, Power, Politics in the Decision-Making of Chinese Courts, 3 InTERnATIONAL JOURNAL OF LAW IN CONTEXT 203 (2007).

${ }^{70}$ For an explanation about the significance of the distinction between Party institutions and state institutions, see Ling Li, "Rule of law" in a Party-state - A conceptual interpretive framework of the constitutional reality of China, 2 ASIAN JOURNAL OF LAW AND SOCIETY 93 (2015).

71 People's congresses have higher standing in the state structure, at least nominally. They are usually referred to as "legislative institutions (lifa jiguan)" and not included as a member of the "political-legal institutions". Military courts of the People's Liberation Army and the Para-Military Police are also members of the "political-legal institutions" but their involvement in ordinary judicial and law enforcement activities is evidently limited compared with other institutions listed in the main text. 72 See Organizational Law, supra note 56. Art. 18.
} 
included: to steer, arrange, check and inspect the work of the Ministries of Civil Affairs, Justice and Public Security. In addition, as the state was in its infancy, the Committee was also mandated to set up state agencies and perform some civil services, such as providing veteran benefits and relief. ${ }^{73}$ When the constitution was amended in 1954, the legislative, executive, prosecutorial and judicial powers were separated, as explained in the previous section. Under the new party-state structure, it became evidently inappropriate to have a committee under the State Council to monitor judicial affairs. Thus, the State Council Political-Legal Committee was dissolved. In its place, the party established the Central Party Legal Committee directly under the Central Party Committee. The Central Party Legal Committee was mandated to undertake assignments of the Central Party Committee, to review party principles and policies on legal affairs, to review [institutional arrangements and activities] regarding the division of labor and checks and balances between political-legal institutions. ${ }^{74}$ Meanwhile, the SPC, the SPP and the Ministry of Public Security (MPS) were required to continue to report directly to the Central Party Committee through the party-groups installed in them. ${ }^{75}$

Table 1 List of names of specialized Party political-legal institutions at the national level since 1949

1949-1954 State Council Political-Legal Committee Party-Group

1954-1958 Central Party Legal Committee

1958-1978 Central Party Political-Legal Small Group (with periods of suspension during the 1960s1970s)

1978-1988 Central Party Political-Legal Committee

1988-1989 Central Party Political-Legal Leading Small Group (CPPL-LSG)

1989-present Central Party Political-Legal Committee (CPPLC)

2003-present Central Party Judicial Institutional Reform Leading Small Group (CPJIR-LSG)

In May 1958, Mao reshuffled the Politburo and the Central Party Secretariat at the $5^{\text {th }}$ Plenum of the $8^{\text {th }}$ Party Central Committee. ${ }^{76}$ Immediately afterwards, the Central Party Political-Legal Small Group was established, replacing the Central Party Legal Committee. This Small Group, along with four other Central Small Groups, was expected to bring issues that were previously discussed within the State Council directly to the Central Party Secretariat for deliberation." ${ }^{177}$ Mao was particularly emphatic on this point, making the following remarks in a drafted notice on the establishment of the small groups: "These Small Groups belong to the Central Party, immediately subject to and shall report directly to the

\footnotetext{
73 Meng Hou, "Dang yu zhengfa" guanxi de zhangkai - yi zhengfa weiyuanhui wei yanjiu zhongxin [An Explanation of the Relationship between the Party and the Courts - from the Perspective of the Political-Legal Committee], FAXUE JIA 1, 3 (2013).

${ }^{74}$ See LIU, supra note 57 at footnote 60.

75 Id. at footnote 77.

${ }^{76}$ Zhongguo gongchandang di ba jie zhongyang weiyuanhui lici quanti huiyi [A list of summaries of each plenary session of the 8th Central Party Committee] available at http://news.xinhuanet.com/ziliao/2003-01/20/content_697524.htm, Jan. 20(2003), available at http://news.xinhuanet.com/ziliao/2003-01/20/content_697524.htm.

77 Zonghai Shao, Zhonggong zhongyang gongzuo lingdao xiaozu de zuizhi dingwei [Defining the institutional role of the Central Party Small Leading Groups], 48 DALU YANJIU [MAINLAND RESEARCH] 1 (2005). Chongji Jin, A Biography of Zhou Enlai (1949-1976) 438 $\S 1$ (Central Party Archive Research Office ed., Central Archival Publishing House 1998).
} 
Politburo and the Central Party Secretariat ... [The party-state] only has one institution for political design, not two." ${ }^{18}$ The leader of the first Central Political-Legal Small Group was Peng Zhen, a Politburo member at the time of appointment. Other members included leaders of the MPS, the SPC, the SPP and a deputy prime minister. ${ }^{79}$ In 1959 the Central Political-Legal Small Group expanded to include a few deputy leaders of each of the state political-legal institutions. ${ }^{80}$ During the late $1950 \mathrm{~s}$ and throughout the 1960s, as the political struggle within the party intensified, the focus of the Central Political-Legal Small Group was dominated by anti-revolutionary class struggles. At the same time, political-legal work departments were gradually established in party institutions of most provinces and major cities, to coordinate and inspect political-legal activities on behalf of the provincial or prefectural party committees. ${ }^{81}$

During the Cultural Revolution, as the party institution was dismantled, the Central Political-Legal Small Group also stopped functioning. ${ }^{82}$ The entire state legal system remained paralyzed until the end of the Cultural Revolution when court activities were gradually restored. ${ }^{83}$ In 1978, the procuratorate system was also restored. ${ }^{84}$ Subsequently, in June 1978, the Central Party Political-Legal Small Group was reestablished to assist the Central Party with the task to monitor the activities of the SPC, SPP, MPS and the Ministry of Civil Affairs. ${ }^{85}$ The leader of this new Central Political-Legal Small Group was then Politburo member Ji Dengkui, a previous civilian party cadre who was quickly promoted by Mao to the apex of power from Henan Province during the Cultural Revolution. ${ }^{86}$ The mandate of Ji's Central Political-Legal Small Group included:

1) To pass instructions of the Central Party [to state legal institutions] and to inspect the status of implementation; 2) to coordinate the work of the four state institutions (SPC, SPP, Ministry of Public Security, Ministry of Civil Affairs) according to the principles and policies of the Central Party; 3 ) to preview documents of the four state legal institutions that were submitted to the Central Party for approval and/or dissemination, and to research on important issues that concern party policies and principles; 4) to review and to provide advisory opinions on death penalty cases that require the Central Party's approval and to coordinate controversial cases for which the SPC and local courts or certain party organizations have diverging opinions. ${ }^{87}$

\footnotetext{
78 Zedong Mao, Dui zhongyang jueding chengli caijing, zhengfa, waishi, kexue, wenjiao ge xiaozu de tongzhigao de piyu he xiugai [Mao Zedong's Remarks and Edits of the Central Party's Drafted Notice on the Establishment of the Financial, PoliticalLegal, Foreign Affairs, Science, and Culture and Education Small-Groups], in MAO ZEDONG'S MANUSCRIPTS SINCE THE ESTABLISHMENT OF THE P.R.C. (VoL. 7) (1992).

79 See LIU, supra note 57 at 16 .

$80 / d$.

${ }^{81}$ See Zhong, supra note 53.

82 Guanyu dui gong'an jiguan shixing junguan de jueding [Decision on Imposing Military Control over Public Security Organs] issued by the Central Party in 1967 (1967).

${ }^{83}$ Xiancheng Yang, Zalan gongjianfa he qingli jieji duiwu [Destroying Publis Security Organs, Courts and Procuratorates and

Purging Classes], yanhuang Chunaiu [CHina THROUGH THE Ages] 55 (2013).

${ }^{84}$ See LIU, supra note 57 at 18.

$85 \mathrm{ld}$.

${ }^{86}$ Annoymous, Ji Dengkui suo jingli de rensheng fenglang [The Ups and Downs in Ji Dengkui's Life], DANGSHI BOCAI [PARTY HISTORY Digest] AVAILABLE AT HTTP://CPC.PEOPLE.COM.CN/GB/68742/70423/70424/5280335.HTML Sep. 17, 2014. 2007.

87 See LIU, supra note 57 at 18.
} 
Ji's Central Party Political-Legal Small Group lasted only six months and was replaced by the now wellknown Central Party Political-Legal Committee (CPPLC) after the $3^{\text {rd }}$ Plenum of the $11^{\text {th }}$ CCP National Congress was held at the end of 1978. According to the CPPLC's first director, Peng Zhen, the role of the CPPLC is three-fold. First, it is the Central Party's "consultant" with a mandate to conduct research, provide opinions and propose plans for the party on law-related issues.$^{88}$ Second, it is the Central Party's "organizational agent" with a mandate to marshal various legal institutions, with "unified understanding, unified action, mutual coordination and concerted action", in order to implement decisions made by the Central Party. ${ }^{89}$ Third, it is the Central Party's secretary and must carry out tasks assigned by the Central Party. ${ }^{90}$ Peng Zhen stressed that all party political-legal committees (PPLCs), as assistants to corresponding party committees, are not a first-level (of independent standing) party organizations and their power should not be too broad. ${ }^{91}$

During the 1980s, as the political order was restored and economic reform started, the CPPLC was designated as a permanent division of the party, required to report and answer to the Central Party. The CPPLC was authorized to conduct the following activities:

"[The CPPLC] shall, under the leadership of the Central Party, to examine and handle important issues that have emerged in national political-legal affairs and provide advisory opinions to the Central Party; to assist the Central Party to handle the requests and reports submitted by various legal institutions to the Central Party for instructions, to coordinate all legal institutions, according to the principles, policies and instructions issued by the Central Party, so as to unify action, unify strategic planning and unify implementation regarding common and overarching issues that concern all legal institutions; to conduct research and survey regarding the status of implementation of party principles, policies and state laws and regulations; to conduct research and investigation regarding the state of organizational affairs and thoughts of political-legal staff; to perform other assignments from the Central Party." ${ }^{92}$

The notice made it clear that the power of the CPPLC is derived from the authorization from the Central Party. In other words, the Central Party remains as the highest decision-making body on, inter alia, judicial affairs, not the CPPLC. To avoid confusion, the Notice [1980] provided: "after the establishment of the CPPLC, each national [state] political-legal institution shall continue to report to the Central Party, State Council and the Central Military Committee." ${ }^{\prime 3}$ This was reiterated in the Central Party's Instruction regarding the Enhancement of Political-Legal Work (1982): Party-secretaries of party

\footnotetext{
${ }^{88}$ Zhen Peng, Zai zhongyang zhengfawei diyici huiyi shang de jianghua jiyao [Summarized Scripts of the Speech at the First Meeting of the Central Political-Legal Committee], in Lun XINZHongGuo de ZHengfa Gongzuo [ON THE Poltical-Legal Work of NeW CHINA] (Zhen Peng ed. 1992).

${ }^{89} / d$.

$90 / d$.

91 See LIU, supra note 57 at footnote 108. See also: FUzHI LIU, MEMOIRE OF LIU FUZHI 306 (2010).

${ }^{92}$ Zhonggong zhongyang guanyu chengli zhengfa weiyuanhui de tongzhi [Central Party's Notice on the Establishment of Political-Legal Committee] issued by the Central Party in 1980. ${ }_{93} / d$
} 
committees shall personally check political-legal work and the party-secretaries of PPLCs shall refer important issues to party committees for collective decision making. ${ }^{94}$

Throughout the 1980s, the PPLCs nationwide mostly engaged in anti-crime "strike-hard" campaigns, where cases were processed swiftly with procedural requirements frequently neglected and heavy sentences applied to the accused. ${ }^{95}$ Meanwhile, as the party launched the economic reforms, the concomitant reform to separate the party and the state (separation reform) was also expedited. In 1988, at the height of the separation reform, the party decided to downsize the party administration and dissolve party departments and divisions that have corresponding state institutions that perform the same regulatory functions. The CPPLC was disbanded for a short time in 1988 and replaced by the Central Party Political-Legal Leading Small Group (CPPL-LSG), led by the newly elected Politburo Standing Committee member, Qiao Shi. ${ }^{96}$

The CPPL-LSG was one of about a dozen central leading small groups that bourgeoned in numbers since the 1980s. ${ }^{97}$ The central leading small-groups deliberate national policies at the highest level and yet they have no status in the Party Charter. Almost all central leading small-groups are led by members of the Politburo Standing Committee and have become the highest authorities for their respective regulatory sectors. ${ }^{98}$ Other members of these central leading small groups are drawn from key party and state institutions that undertake corresponding regulatory responsibilities..$^{99}$ At the inception of the CPPL-LSG, Secretary Qiao Shi, its director, stressed that the replacement of the CPPLC with the CPPL-LSG shall not be understood as the relaxation of the party's control over political-legal affairs but rather a shift of the party's governing approach. ${ }^{100}$ According to Qiao, some party leaders had been too busy interfering with the operation of judicial institutions and some too timid to claim authority. ${ }^{101}$ Qiao criticized both approaches and stated that both should be rectified. ${ }^{102}$ However, the life of the CPPL-LSG was cut short by the political turmoil in 1989. After the party had reinstalled political order, the CPPLLSG was dissolved and the CPPLC was resurrected. Qiao Shi continued to act as the CPPLC's director.

Under Qiao Shi's leadership, the CPPLC was positioned "to steer and coordinate political-legal affairs in a macro manner". Following the principle of the party-state separation reform that survived the 1989 political crisis, PPLCS were required not to "over-interfere with the details of the work of legal

\footnotetext{
${ }_{94}$ Zhonggong zhongyang guanyu jiaqiang zhengfa gongzuo de zhishi [Central Party's Instruction on Enhancing the Political-Legal Work] issued by the Central Party on Jan. 13, 1982.

${ }_{95}$ Min Cui, Bashi niandai "yanda" de huigu yu fansi [A Review and Reflection on the "Strike-Hard" Campaigns in the 1980s], yanhuANG Chunqui [China through the Ages] Ava 16 (2012).

${ }_{96}$ Central Bianzhi Office, Zhonggong zhongyang jigou yange gaiyao [A Chronology of the Central Party Institutions] (2011). Haoping Qian, lingdao xiaozu zenyang "lingdao" [How Does the "Leading Small-Group" Lead?], Nanfang Renwu WeEkLY Sep. 5. 2012. Speical Report, Xiaozu ruhe zhi daguo [How Do "Small-Groups" Govern A Big Country?] (2014).

${ }^{97}$ Office, Zhonggong zhongyang jigou yange gaiyao [A Chronology of the Central Party Institutions]. 2011. Also see Alice Miller, The CCP Central Committee's Leading Small Groups, CHINA LEADERSHIP MONITOR (2008).

${ }^{98} / d$.

${ }^{99}$ See Shao, supra note 77.

${ }^{100}$ Annoymous, Qiaoshi xinshu pilu zhengfawei chexiao yu huifu bufen xijie [Details about the revocation and resurrectment of the PPLC revealed in Qiao Shi's new book], CAIXIN NETWORK. available at http://china.caixin.com/2012-06-21/100403122.html, published on Jun. 21, 2012

$101 / d$.

$102 / d$.
} 
institutions ... in order to ensure that courts and procuratorates can exercise their power independently". ${ }^{103}$ In the 1990s, the CPPLC experienced its greatest institutional expansion as it was merged with the Central Social Security Comprehensive Management Committee (zhongyang shehui zhian zonghe zhili weiyuanhui). ${ }^{104}$ At the same time, the CPPLC was structurally strengthened and became a self-contained component of the party apparatus, with offices established in local party organizations from the provincial down to county levels. Heads of these local PPLCs have since then been granted memberships in local party standing committees. ${ }^{105}$

Currently, the PPLCs conduct the following court-related activities:

\begin{abstract}
1) To unify the thoughts and actions of all political-legal institutions according to party lines, principles, policies and plans of party committees; 2 ) to make periodic plans regarding all dimensions of the political-legal affairs and be responsible for its implementation; 3) to inspect the performance of all political-legal institutions regarding the implementation of law and party principles and polices and to examine and develop concrete measures, based on practical conditions, to ensure loyal implementation of law and party principles and policies; 4) to provide support to and strictly monitor all political-legal institutions regarding their exercise of power in compliance with the law, to steer and coordinate close collaboration between these institutions without impeding the checks and balances; to push the investigation and handling of major and important cases, to examine and discuss those important, unclear and hard cases over which diverging opinions exist; 5) to organize, coordinate activities concerning public safety and social security, to ensure social stability and to push all parties concerned to implement relevant policies and measures 6) to organize and push research work concerning activities of all political-legal institutions; 7) to examine and strengthen measures regarding team building and leadership building in political-legal institutions, to assist party committees and party organizational departments to vet and manage executive cadres in political-legal institutions; to assist party discipline and inspection committees and state supervision and inspection institutions to investigate legal infractions and disciplinary violations committed by political-legal cadres; 8) to steer the work of subordinate PPLCs; 9) to perform other tasks assigned by the party committee and the PPLC at the superior level. ${ }^{106}$
\end{abstract}

The latest and also the most powerful specialized party political-legal apparatus is the Central Party Judicial Institutional Reform Leading Small Group (CPJIR-LSG). It was first established in 2003, led by Luo Gan, a member of the Politburo Standing Committee. Luo was succeeded by Zhou Yongkang, the now infamous fallen "tiger" captured and convicted at the height of the 2012-present anti-corruption campaign. Compared with the CPPLC, whose primary function is to coordinate and conduct routine inspection over political-legal institutions, the CPJIR-LSG enjoys the highest decision making authority on policies related to the state judicial system. Unlike the CPPLC, whose mandates are limited to courts and other law enforcement institutions, the CPJIR-LSG draws its members from a much wider range of institutions including the CPPLC, the SPC, the SPP, the Ministry of Public Security, the Legal Affair Office

\footnotetext{
${ }^{103}$ Zhonggong zhongyang guanyu weihu shehui wending jiaqiang zhengfa gongzuo de tongzhi [Notice on Reserving Social Stability and Enhancing Political-Legal Work] issued by the Central Party on Apr. 2, 1990.

${ }^{104}$ Zhonggong zhongyang zhengfa weiyuanhui guanyu jiaqiang geji dangwei zhengfa weiyuanhui gongzuo de tongzhi [Notice on Enhaning the Work of Party Committee Political-Legal Committee of All Levels] issued by the Central Party in 1995.

105 Id.

${ }^{106}$ Functions and Responsibilities of Ruzhou City Party Political-Legal Committee (Ruzhou Political-Legal Network, available at http://www.rzzfw.gov.cn/News_View.asp? NewsID=317). ZHONGLIANG LIN, GEJI DANGWEI ZHENGFAWEI DE ZHINENG JI HONGGUAN ZHENGFA gongzuo [Functions and Macro Political-Legal Work of Party Committee Political-Legal Committee of All levels] (2004)
} 
of the State Council, the Central Party Bianzhi ${ }^{107}$ Commission Office (which is involved in administering the ranking system) and the National People's Congress. ${ }^{108}$ Its authority extends far beyond "coordination" between the political-legal institutions but also the coordination between political-legal institutions with other state institutions, including the legislature, treasury and personnel regulatory authorities. ${ }^{109}$

During their respective terms, Luo and Zhou each held leadership positions in both the CPPLC and the CPJIR-LSG. In 2012, when the once-in-a-decade power transition in the Party was scheduled, an unexpected chain of events led to the downfall of Zhou Yongkang apparently as a result of a suspected conspiracy with former Politburo member Bo Xilai. Reportedly, Zhou and Bo schemed to "stage a palace coup" against the newly anointed leadership. ${ }^{110}$ In the wake of the scandal, the party terminated the fusion of the leaderships of the CPPLC and the CPJIR-LSG. The Politburo Standing Committee was downsized, eliminating the seat that was previously allocated for the head of the CPPLC. The current leader of the CPPLC is Meng Jianzhu, former leader of the Ministry of Public Security. Unlike his predecessors, he does not enjoy a seat in the Politburo Standing Committee, the highest decisionmaking body of the party. At the same time, the CPJIR-LSG remains active, currently leading the by far most extensive judicial institutional reforms since courts were restored in the early $1980 \mathrm{~s} .{ }^{111}$ The membership of the CPJIR-LSG is also expanding as it was announced that Huang Xiaowei, a standing committee member of the Central Discipline and Inspection Committee, was appointed as its newest member. ${ }^{112}$ However, the identity of the leader of the Central Political-Legal Leading Small Group remains undisclosed. ${ }^{113}$

\section{Mechanisms of control}

As explained in Section III, the party plays a prominent role in regulating court activities. It engages with judicial decision making mostly through the specialized party political-legal apparatuses, most frequently, the PPLC. In general, the PPLC exercises control over judicial affairs through two approaches: 1) the "macro" approach - by instructing courts on certain judicial policies; 2) the "micro" approach - by instructing courts on judicial outcomes of specific cases.

\footnotetext{
${ }^{107}$ For more on the topic of bianzhi, see Kjeld Erik Brødsgaard, Institutional Reform and the Bianzhi System in China, 170 CHINA QUARTERLY (2002).

108 Xudong Qin, zhongyang sifa tizhi gaige lingdao xiaozu jiexi [An Illustration of the Central Judicial Institutional Reform Leading Small-Group], CAIXIN NETWORK, Jan. 19. 2014.

${ }^{109}$ Annoymous, Zhou Yongkang: quanmian luoshi yi chutai de sifa tizhi gaige gexiang cuoshi [Zhou Yongkang: Full Implementation of All Judical Institutional Reform Measures], XINHUA NEWS AGENCY, Jan. 20. 2012.

${ }^{110}$ Benjamin Kang Lim, et. al., Special Report - The power struggle behind China's corruption crackdown, ReUTER, May $23,2014$.

${ }^{111}$ See special column at the People's Network dedicated to the judicial institutional reforms at http://legal.people.com.cn/GB/43027/182218/.

112 See public notice of the appointment at http://renshi.people.com.cn/n/2014/0115/c139617-24120999.html

${ }^{113}$ Although Xi Jinping, the current General Party-Secretary, is most likely the leader of this leading small-group, this speculation has never been officially confirmed. See Qin, supra note 108.
} 


\section{The "macro" approach}

Here, judicial policies refer to those rules that regulate judicial discretion and that are issued by courts under instructions of the party. The line between what qualifies as judicial policies and what qualifies as legislative matters is never clearly drawn. Since judicial policy-making is not bound by the deliberation, public participation and voting procedures that are mandatory for the legislative process, judicial policies are issued with greater frequencies and in greater numbers. Such policies may appear in the form of judicial interpretation (sifa jieshi), opinion (yijian), decision (jueding) or notice (tongzhi). ${ }^{114}$ Even though these policies have more of an ad hoc nature and may change as the leadership or the preference of the leadership shifts, they have a significant impact on the exercise of judicial power because of their immediate effect upon day-to-day court activities.

The party selectively engages in judicial policy-making either upon its own initiative or upon requests from courts and/or other state institutions. The party is likely to take initiatives and instruct courts to issue certain judicial polices if concerted judicial actions are deemed a necessary step to enforce particular regulatory policies that the party is advancing at the time. For example, in 1998 the Central Party launched a campaign against foreign currency purchase fraud as an effort to eradicate smuggling and to enhance the central government's regulatory capacity over economic activities. ${ }^{115}$ Following the party's campaign initiative, the National People's Congress Standing Committee first amended the Criminal Code, which criminalized acts involving foreign currency purchase based on false documentation and unauthorized trade of foreign currency. ${ }^{116}$ The SPC followed suit and issued a judicial policy, which reaffirmed the criminalization of the targeted conduct and clarified issues concerning the application of the new legal provision. ${ }^{117}$

Local party institutions are also entitled to engage in judicial policy making within their territorial jurisdictions as long as such policies are consistent with those applied nationwide. For example, in 2003, the Beijing PPLC issued a policy that authorized procuratorates to withdraw prosecutions and courts to exempt criminal punishment regarding misdemeanor offenders if the offender had shown remorse, provided retribution to the victim(s) and was forgiven by the victim(s). ${ }^{118}$ Similarly, the Chongqing PPLC

\footnotetext{
${ }^{114}$ The SPC has been frequently criticized by the National People's Congress (NPC) for encroaching the NPC's legislative power through its activities to issue judicial interpretations. Urged by the NPC, in 2012 the SPC identified 1,600 pieces of judicial interpretations (about half of the total number of judicial interpretations that the SPC has issued) for review and decided to revoke 715 of them. For a report on this project and related criticism of the SPC, see Hao Yu, Sifa jieshi "shoushen" chenggong [Successful "Shrink" of Judicial Interpretations], ZhongGuo Renda [CHINA's PeOPLE's Congress JouRnal] 32 (2013).

115 Annoymous, Zhu Rongji zai basheng(qu) daji zousi he pianhui gongzuo zuotanhui shang qiangdiao zhichu jianding buyi di yanli daji zousi fanzui [Firmly strike against smuggling: Zhu Rongji said at the eight-provinces (districts) symposium on striking against the crimes of smuggling and obtaining foreign currency by fraud], FUIIAN SANMING DAILY NEWSPAPER, 1998. Available at http://www.66163.com/fujian_w/news/smrb/981026/4-1.htm.

${ }^{116}$ Quanguo renda changweihui guanyu chengzhi piangou waihui, taohui he feifa maima waihui fanzui de jueding [Decision on Punishing and Regulating Crimes of Faudulent Purchase of Foreign Currency , Illegal Deposit, Sale or Transfer of Foreign Currencies and Illegal Trading of Foreign Currencies] issued by the NPC in 1998.

117 Guanyu shenli piangou waihui, feifa maimai waihui xingshi anjian juti yingyong falv ruogan wenti de jieshi [Judicial Interpretation on Adjudicating Criminal Cases involving Fraudulent Purchase of Foreign Curriences and Illegal Depositing, Selling and Transferring Foreign Currencies] issued by the Supreme People's Court on Aug. 28, 1998.

118 Zhusheng Ye, zhengfawei xietiaohui jizhi mianlin gaige [Political-Legal Committee Coordinating Meeting Mechanism Faces Change], NAN Feng ChuANG, May 9. 2014. Available at http://www.nfcmag.com/article/4730.html.
} 
had been holding annual meetings and issuing criminal judicial policies that ranged from substantive legal issues including the factual threshold for prosecution regarding specific offenses, the labeling of offense, sentencing guideline for certain offenses, interpretation of the legal definition of identified crimes to procedural protocols regarding evidence collection, transfer of detainees, paperwork required to interrogate or interview suspects and even protocols concerning case-file loans (i.e. to provide access to case-files upon requests by other political-legal institutions). ${ }^{119}$

When the party engages in judicial policy-making, such activities often take place in conferences and meetings, hosted by PPLCs. Individual party leaders can also make oral or written instructions (known as zhishi or pishi), within their authority, and demand courts to develop policies in identified areas. For example, between 2010 and 2011, the SPC received instructions (pishi) from central party leaders on dealing with widely reported food safety scandals and then issued a series of notices urging courts nationwide to increase the severity of punishment to food safety regulation violations. ${ }^{120}$ In 2013 , the Central Party further prioritized food safety regulation and shifted its focus from simply punishing violators to enhancing regulatory capacity. ${ }^{121}$ Concurrently, the SPC issued a judicial policy addressing food/drug safety issues by enhancing the protection of consumers' rights and applying stricter liabilities on the part of food/drug manufacturers, sellers and food/drug safety regulators. ${ }^{122}$

When the party takes initiatives to make judicial policies, very often, it engages not only courts but also other state institutions whose activities will be affected by these policies. This is particularly common for policies concerning criminal law. It is because criminal cases involve activities of at least two other state institutions: procuratorates and the police. For example, during the aforementioned campaign against foreign currency purchase fraud, the party summoned the SPC, the SPP and the MPS to meet together and align their policies and efforts in order to achieve the optimal outcome for the campaign. ${ }^{123}$ The coordination resulted in a decision, which covered issues ranging from jurisdictional disputes between the procuratorates and the public security bureaus, interpretation of the definition of the crime to sentencing policies. ${ }^{124}$ Once issued, the decision was circulated to courts, procuratorates and public security bureaus nationwide for implementation. ${ }^{125}$ A more recent example of the party's "coordination" initiative is the two guiding opinions (zhidao yijian) issued by the CPPLC in 2013 and 2014 respectively. The one issued in 2013 concerns prevention of wrongful convictions. The one issued in 2014 concerns

\footnotetext{
${ }^{119}$ Chongqingshi zhengfa bumen wuzhang lianxi huiyi jiyao [Memo of the Joint Meeting of the Chiefs from the Five PoliticalLegal Institutions of Chongqing City] circulated on Jul. 4, 2000.

120 The report did not reveal the name(s) of the "central leader(s)" who gave and sent the instructions. See the report at Zuigaoyuan: zhongda shipin anquan an yifa congzhong panchu [Supreme People's Court: Aggregating Sentences Shall be Applied to Serious Food Safety Cases] published on May 27, 2011; available at http://www.sina.com.cn. (2011).

121 Haiyan Ma, dang shipin anquan pai zai jingji fazhan shouwei [When Food Safety Is Put at the Top of Economic Development Agenda], Sina FinANCE Column 2013.

${ }^{122}$ guanyu shenli shipin yaopin jiufen anjian shiyong falv ruogan wenti de guiding [Rules on Application of Laws in Cases Related to Food and Drugs Disputes] issued by the Supreme People's Court on Dec. 9, 2013.

${ }^{123}$ Banli pianhui taohui fanzui anjian lianxi huiyi jiyao [Memo on the Joint Conference on the Handling of Cases involving Fraudulent Purchase of Foreign Curriences and Illegal Depositing, Selling and Transferring Foreign Currencies] issued jointly by the SPC, SPP and MPS in 1999.

124 Id.

125 Guanyu yinfa banli pianhui, taohui fanzui anjian lianxi huiyi jiyao de tongzhi [Notice on the Dissemination of the Memo on the Joint Conference on the Handling of Cases involving Fraudulent Purchase of Foreign Curriences and Illegal Depositing, Selling and Transferring Foreign Currencies issued by the SPC, SPP and MPS in 1999].
} 
judicial examination of applications for sentence reduction and parole. Following these initiatives, the SPC, the SPP and the MPS all issued corresponding policies, translating the CPPLC's opinions into concrete operational procedures of their own, which were then circulated to courts, procuratorates and public security bureaus nationwide for implementation. ${ }^{126}$

In the examples mentioned above, the party exercised its policy-making power by giving courts more or less clear guidelines for policy development. On other occasions, the party provided very general and broad outlines and left it to courts to flesh them out. For example, in 2006, the Central Party made "constructing harmonious society" as the thematic principle for the governance of the party-state. The SPC subsequently developed a series of judicial policies, translating the abstract principle into operational judicial practices, including the well-known policy of balanced sentencing in criminal cases based on the nature and the totality of circumstances of the specific case concerned ${ }^{127}$ and the widely criticized policy that prioritized mediation over adjudication. ${ }^{128}$

Other than dictating judicial policies, the party also acts as a paternalistic arbiter, solving disputes between courts and other state institutions and coordinating their demands and interests. For example, when the Criminal Procedural Law was promulgated in 1997, it caused great controversy between courts and procuratorates regarding the staging of courtrooms and rules on court decorum. ${ }^{129}$ Specifically, courts and procuratorates disagreed on the height of the judges' bench vis a vis that of the prosecutors' desk. ${ }^{130}$ Disagreement also persisted regarding whether prosecutors should stand up, the same as the defendants and defense attorneys are required to do, upon judges' entrance to courtrooms. ${ }^{131}$ These issues were not as trivial as they may appear to be since procuratorates took the value of symbolism seriously and argued that they enjoyed the same rank as courts and hence should

\footnotetext{
126 Guanyu jianli jianquan fangfan xingshi yuanjiacuoan gongzuo jizhi de yijian [Opinions on the Establishment and Completing the Operating Mechanism to Prevent Wrongful Convictions] issued by the Supreme People's Court in 2013. Guanyu qieshi Ivxing jiancha zhineng fangzhi he jiuzheng yuanjia cuoan de ruogan yijian [Several Opinions on Truthfully Performing the Prosecutorial Duty to Prevent and Rectify False Convictions] issued by the Supreme People's Procuratorate in 2013. Guanyu jinyibu jiaqiang he gaijin xingshi zhifa ban'an gongzuo qieshi fangzhi fasheng yuanjia cuoan de tongzhi [Notice on Further Strengthening and Improving Criminal Enforcement Activities and Reliably Preventing Wrong Cases] issued by the Ministry of Public Security in 2013. Guanyu jianxing, jiashi anjian shenli chengxu de guiding [Rules on the Adjudicative Procedure regarding Reduction of Sentences and Paroles] issued by the Supreme People's Court in 2014. , Sifabu yaoqiu jinyibu guifan jianyu jianxing, jiashi, zhanyu jianwai zhixing gongzuo [Ministry of Justice Requires Justice Administrative Bureaus to Further Strengthen the Regulation of Sentence Reduction, Parole and Conditionally Serving Sentence out of Prison] issued on Mar. 14, 2014; available at http://www.moj.gov.cn/Discipline_Inspection/content/2014-03/14/content_5362149.htm?node=39174, MINSTRY OF JUSTICE WeBSITE, 2014. Notice on Forwarding the Central Party Political-Legal Committee's Opinion on Strengthening the Regulation on Reduction of Sentence, Parole and Conditionally Serving Sentence out of Prison and Reliably Preventing Judicial Corruption issued by Xiang Yang City Justice Bureau in 2014. Annoymous, Central Party Political-Legal Committee Issued Guiding Opinion on Strengthening the Regulation on Reduction of Sentence, Parole and Conditionally Serving Sentence Out of Prison to Enhance Judicial and Enforcement Credibility, LEGAL DAILY, Feb. 25. 2014.

127 guanyu guanche kuanyan xiangji xingshi zhengce de ruogan yijian [Opinions on Implementing the Policy to Balance Leniency and Rigidity in Criminal Cases] issued by the Supreme People's Court in 2010.

128 For example, see Minzner, supra note 10.

${ }^{129}$ Zhonggong zhongyang zhengfawei guanyu shishi xiugai hou de xingshi susongfa jige wenti de tongzhi [Central Party PoliticalLegal Committee's Notice on A Number of Issues regarding the Implementation of the Amendment of the Criminal Procedure Law] issued by the CPPLC in 1997.

$130 / d$.

$131 / d$.
} 
not be subjugated to the authority of courts. ${ }^{132}$ The controversy was eventually arbitrated by the CPPLC, which decided that all parties, including the prosecutors, should remain seated upon entrance of judges and all should stand up when the judge announced court judgment, a symbolic act to manifest the authority and reverence of the law of the state. ${ }^{133}$ The CPPLC also "ruled" that judges' benches should be placed in the middle of courtrooms and could be placed on a raised podium on the grounds that an elevated bench would ensure that all participants have a clear view of the judges, who are the central figures in court proceedings after all. ${ }^{134}$

Other than arbitrating on disputes over courtroom furniture placement and decorum, the party engages in coordinating activities more frequently to secure resources and/or command compliance with court decisions by other state institutions that are beyond the reach of courts. For example, in 1999, the SPC submitted a report to the Central Party. ${ }^{135}$ In the report, the SPC called for the party's attention to the enforcement problem that courts were facing in civil and commercial cases. The problem was caused by the fact that courts had no authority to compel compliance or cooperation from equally ranked state agencies that hold assets or information of the assets that courts are pursuing. ${ }^{136}$ These agencies include various asset registration agencies, residents' registration agencies, business registration agencies, banks and tax and other financial regulators. ${ }^{137}$

The Central Party acknowledged the problems and circulated the SPC report to relevant authorities with an instructive remark, demanding local authorities to help preserve the authority of court judgments. ${ }^{138}$ The circular produced limited effect. In the years that followed, the SPC continued to seek support from various party authorities. ${ }^{139}$ In 2010, the SPC announced an opinion signed by 19 party and state institutions and agencies, including the Central Committee of Discipline and Inspection (CCDI), the Central Organizational Department (COD) and the Central Propaganda Department (CPD). The opinion calls for the establishment of "a liaison and mobilization mechanism for court enforcement" at every administrative level. ${ }^{140}$ In the opinion, both the CCDI and COD agreed to investigate disciplinable conduct that involves obstruction and interference of court enforcement efforts if information concerning such conduct is collected during their routine work. ${ }^{141}$ The CPD agreed to publicize noncompliance conduct on official media and all other agencies agreed in principle to provide assistance

\footnotetext{
132 Zongzhi Long, Jianchaguan gaibugai qili - dui tingshen yishi de yizhong sikao [Should Prosecutors Stand Up - A Reflection On the Rituals of the Trial], 3 FA XUE 44 (1997).

133 See supra note 129.

134 ld.

135 Zhonggong zhongyang guanyu zhuanfa zhonggong zuigao renmin fayuan dangzu guanyu jiejue renmin fayuan zhixingnan wenti de baogao de tongzhi [Notice on the Forwarding of the Supreme People's Court Party-Group's Report on Solving the Problem of Enforcement Difficulties] issued by the Central Party in 1999.

$136 / d$.

137 Id.

138 Id.

139 Wei Liu, ershi ge zhongyang jigou zhixing liandong jizhi pojie fayuan zhixing nan [Twenty Central Institutions Take Joint Actions to Solve the Obstacles in Enforcing Court Judgments], MinzHu yu FazHI SHIBAO [DEMOCRACY AND Rule by LAW TIMES], Jul. 26. 2010.

140 guanyu jianli he wanshan zhixing liandong jizhi ruogan wenti de yijian [Opinions on Establishing and Completing the Joint Action Mechanism for Court Judgement Enforcement] jointly issued by the Supreme People Court and other 19 central institutions in 2010. ${ }^{141}$ Id.
} 
and share information with courts for the purpose of asset recovery and forfeiture. ${ }^{142}$ The SPC congratulated itself on the issuance of this opinion and considered it a big step forward in improving the problems of judgment enforcement. ${ }^{143}$ However, in practice, none of these measures would overcome the structural constraints that had caused the enforcement problem. As explained in Section II, the reason that courts cannot compel compliance with the law by other state institutions of the same or higher rank is because courts are constricted to the power structure that is designed to preserve the supreme authority of the party over the state, including courts. This power structure is a much harder constraint that cannot be overruled by any of the general, non-specific and non-binding opinions that the party has agreed to sign on. In other words, as long as this power structure remains intact, it is conceivable that courts would still need to ask the party on a case-by-case basis for concrete instructions to compel specific institutions to comply with court decisions that the party has endorsed.

This section explained why and how the party exercises supervisory power to engage in judicial policy making in order to ensure that the work of courts is aligned with political objectives and priorities of the party. Compared with the legislative process (which the party also supervises), regulating judicial activities through judicial policy-making is more convenient, efficient and flexible. However, to reserve the judicial policy-making power alone is not sufficient to secure control over judicial affairs for the purpose of self-preservation. It is because policies are not specific enough to inform courts what kind of judicial outcome the party would expect in specific cases, for example, cases that are of great political significance for the party. Therefore, the party needs a channel to "micro-manage" court activities, in addition to the "macro" approach explained above.

\section{The "micro" approach}

The "micro" approach is the approach to secure direct access to judicial decision-making in individual court cases so that the party can, whenever it deems necessary, control the judicial outcomes of these cases. In the party's early history, dictating judicial outcomes had been an inherent feature of judicial practices. In the party-controlled border-regions during the 1930s, all court decisions on criminal cases had to be approved by party committees before these decisions were issued. ${ }^{144}$ This "case-approval" practice continued to dominate court activities after the establishment of the P.R.C in 1949. ${ }^{145}$ At times, the police, procuratorate and courts, worked jointly together, led by the party, on high-profile cases. The practice was called "joint-case-handling (lianhe ban'an)", where all these institutions would formulate investigative, prosecutorial and adjudicative plans together towards the intended judicial outcome. ${ }^{146}$ Enjoying the efficiency generated by the practice of joint-case-handling, Peng Zhen, the head of the then Central Party Political-Legal Small Group, explained: "The practice of joint-case-

\footnotetext{
$142 / d$.

${ }^{143} \mathrm{Id}$.

${ }_{144}$ Quan'e Liu, shanganning bianqu sifa gaige yu "zhengfa chuantong" de xingcheng [Judicial Reform in Shanganning BorderRegion and the Establishment of the "Political-Legal Tradition"], Doctoral THESIS (JILIN UNIVERSITY) (2012).

145 Yongkun Zhou, zhengfawei de lishi yu yanbian [The History and Vicissitude of the Political-Legal Committee], YANHUANG CHUNaIU [CHINA THROUGH THE Ages] 7 (2012).

146 See Hou, supra note 73 at 4 . Also see Chapter 1, Section 3 - Cultural Revolution Era, AdJudication IN SHAANXI CouRTS SINCE THE ESTABLISHMENT OF THE P.R.C. Available at http://www.sxsdq.cn/dqzlk/sxsz/spz/200903/t20090330_6400.htm.
} 
handling is not only possible but truly necessary. [Because for] so many cases [that we have], if you do your part, I do my part, without face-to-face communication and deliberation, how can it work?"147 Later in the 1950s, at times, the SPC, the SPP, the MPS and the MOJ were even merged into one as the result of government downsizing. ${ }^{148}$

After the Cultural Revolution, the party issued the well-known No.64 Document that terminated caseapproval practice. ${ }^{149}$ It means that courts no longer need to obtain approval from the party before they make a decision on every single case. However, since then up till present time, the party has reserved the power to engage in decision-making in certain categories of cases that are deemed important. The party exercises this power mainly through one of two procedures: case coordination and case supervision. In theory, case coordination is a procedure that various political-legal institutions can work together so as to remove the "gridlock" that is likely to prevent a case from being closed timely and/or fairly. ${ }^{150}$ According to local PPLC regulations, ${ }^{151}$ cases that are typically eligible for coordination include: 1) cases that may result in delay or unfair decision because they involve jurisdictional disputes [between different but equal state agencies], disagreements on the facts of a case, characterization of the alleged offense or application of law; 2) cases that have jurisdiction-wide impact upon political social stability and economic development and hence require collaborated efforts from various state institutions; 3 ) new cases for which one cannot find clear rules in current laws, regulations and policies; 4) other cases that the PPLC considers necessary for coordination. The party can decide to "coordinate" a case on its own initiative or upon requests by courts or other institutions.

For cases marked for coordination, the PPLC is entitled to summon responsible institutions and officials who are handling the case to report to the PPLC in coordination meetings. ${ }^{152}$ Once a consensus is reached, it will be formulated as a PPLC opinion, which will then be disseminated in the form of a memo to relevant institutions for implementation. ${ }^{153}$ Instructions sent by the party to courts are often outcome-oriented and supported by no legal reasoning. Sometimes such instructions have the exact terms of the expected verdict specified. For example, in a handful of cases involving selling tobacco without a license, the Hubei Qianjiang PPLC once instructed, through coordination, the relevant court to

\footnotetext{
147 See Peng, supra note 51.

148 See Hou, supra note 73 at 4.

${ }^{149}$ guanyu jianjue baozheng xingfa xingshi susongfa qieshi shishi de zhishi [Instructios on Firmly Guarantee the Reliable Implementation of the Criminal Law and the Criminal Procedure Law] issued by the Central Party on Sep. 9, 1979.

150 Zhongyang zhengfawei ganyu dangwei Zhengfa Weiyuanhui Dui Zhengfa Bumen Zhifa Huodong Jinxing Jiandu De shishi xize [Operational Manual on Party Political-Legal Committees' Supervisory Activities over Law Enforcement Activities of PoliticalLegal Institutions] issued by Qinghai Province Party Political-Legal Committee in 2012 (http://www.chinapeace.gov.cn/201301/05/content_6256436.htm). Guanyu dangwei zhengfa weiyuanhui dui zhengfa bumen zhifa huodong jinxing jiandu de guiding [Rules on Party Political-Legal Committees' Supervisory Activities over Law Enforcement Activities of Political-Legal Institutions] jointly issued jointly by the Central Party Political-Legal Committee, Central Party Discipline and Inspection Committee, Central Party Organizational Department and Central Political-Legal Institutions in 2011.

151 Tongren shi zhengfawei anjian xietiao ducha gongzuo shixing banfa [Provisionary Rules on Case Cordination and Inspection Work] issued by Tongren City Party Political-Legal Committee in 2012. Zhonggong Zhangjiagang shi zhengfa weiyuanhui zhifa jiandu gongzuo shishi banfa [Operational Rules on Supervision over Law Enforcement] issued by Zhangjiagang City Party Political-Legal Committee in 2010. Hunan sheng zhengfawei anjian duban xietiao gongzuo zhidu [Rules on Case Supervision and Coordination] issued by Hunan Provice Party Political-Legal Committee in 2011.

$152 / d$.

$153 / d$.
} 
ensure that "all defendants should be sentenced prison terms without probation". ${ }^{154}$ Sometimes the intended outcome is camouflaged with politically correct slogans, such as "handle the case with caution according to the law" ${ }^{155}$ The obligation to interpret the true intention of such instruction lies in whoever is expected to implement the instruction. ${ }^{156}$ In either scenario, courts are explicitly required to NOT cite party instructions in their decisions as the source of authority for those decisions. ${ }^{157}$

In addition to case coordination, the party can shape or influence judicial outcomes of specific cases through the case inspection procedure, which is distinguished from case coordination in theory but often meshed with the latter in practice. Unlike case coordination (which is primarily used to overcome the checks and balances), case inspection is invoked primarily to investigate and solve complaints about non-compliance with party policies and state laws. According to the relevant regulations, cases that are under inspection are cases that concern preservation of social stability or state security and cases of significant [political and/or social] impact, petitioned cases that have caused strong public reaction, significant cases that can potentially cause serious [political and/or social] problems, and cases involving unlawful conduct of political legal officials. ${ }^{158}$

The same as with" case coordination", a PPLC may invoke a case inspection procedure either on its own initiative or upon requests from two channels. One channel is bottom-up, i.e. from party institutions of the same or lower level. Requests from this channel are limited to cases with significant political, social or economic implication. ${ }^{159}$ The other channel is top-down, i.e. from higher party institutions or leaders. A higher party authority can mark any case and sends it to a PPLC for inspection. ${ }^{160}$ To carry out a case inspection procedure, the PPLC may instruct the responsible political-legal institution(s) that handle(s) the marked case to report its work progress to the PPLC within designated period of time. Such report shall reflect the responsible institution's opinions on the evidence, facts, procedural issues and application of law, and should also include its preliminary decision of the case. ${ }^{161}$ If the responsible institution could not close the case within the designated time, then it is required to provide reasons for the delay. After examination of that reasons provided, the PPLC can decide whether to extend the

${ }^{154}$ See Ye, supra note 118.

155 See Li, supra note 14.

$156 / d$.

${ }^{157}$ Renmin fayuan susong wenshu lijuan guidang banfa [Rules on Filing and Archiving Judicial Documents] jointly issued by the Supreme People's Court and the National Archives Bureau in 1991. Art. 21.

158 Zhonggong huludao shi lianshan quwei zhengfawei zhifa jiandu gongzuo guize [Rules on Supervision over Law Enforcement] issued by Huludao City Lianshan District Party Political-Legal Committee in 2011. Zhonggong Zhangjiagang shi zhengfa weiyuanhui zhifa jiandu gongzuo shishi banfa [Operational Rules on Supervision over Law Enforcement] issued by Zhangjiagang City Party Political-Legal Committee in 2010. Guanyu dangwei zhengfa weiyuanhui dui zhengfa bumen zhifa huodong jinxing jiandu de guiding [Rules on Party Political-Legal Committees' Supervisory Activities over Law Enforcement Activities of PoliticalLegal Institutions] jointly issued jointly by the Central Party Political-Legal Committee, Central Party Discipline and Inspection Committee, Central Party Organizational Department and Central Political-Legal Institutions in 2011. Zhongyang zhengfawei ganyu dangwei Zhengfa Weiyuanhui Dui Zhengfa Bumen Zhifa Huodong Jinxing Jiandu De shishi xize [Operational Manual on Party Political-Legal Committees' Supervisory Activities over Law Enforcement Activities of Political-Legal Institutions] issued by Qinghai Province Party Political-Legal Committee in 2012. Yongzhou shi lengshuitan qu dangwei zhengfa weiyuanhui anjian duban xietiao gongzuo zhidu [Rules on Case Supervision and Coordination] issued by the Yongzhou City Lengshuitan District Party Political-Legal Committee in 2011.

$159 / d$.

$160 / d$.

$161 / d$. 
deadline. If the responsible institution continues to fail to meet the deadline or implement the specific opinion instructed by the PPLC, the PPLC shall propose a solution to the corresponding party committee and the higher PPLC. ${ }^{162}$ Measures of sanctions include public denouncement, revoke of qualification for performance award (including financial reward), suspension and transfer, official party or administrative disciplinary sanction and dismissal of responsible individuals. ${ }^{163}$

Unlike the party's involvement in judicial policy-making, which has been accepted by most Chinese legal academics and practitioners as part of the constitutional reality of the party-state, the party's engagement in judicial decision-making in individual cases has, however, caused increasing public concern. Such concern was heightened when a number of wrongful conviction cases were exposed in the 2000s. ${ }^{164}$ These cases shared a common feature: innocent defendants were accused and convicted for murder by courts under the "coordination" of local PPLCs. ${ }^{165}$ Exposure of these cases had led to heated public discussions and criticisms from the general public and from the legal community. The PPLCs' interference in judicial decision-making in individual cases was blamed for having seriously discredited the judicial system, which has already been suffering from public distrust because of the perceived prevalent judicial corruption in the system. ${ }^{166}$

Under public pressure, the CPPLC formed a series of measures to limit and regulate activities of local PPLCs. Such measures included: 1) demanding local PPLCs not to issue opinions regarding the "determination of the nature of an offense or [other] substantive issues in [individual] cases" ${ }^{\prime 167}$ and 2) declaring the following types of cases or issues not suitable for coordination: cases or issues for which the law or judicial interpretations have clear instructions or cases that should be resolved through legislation or judicial interpretation; requests that are not submitted through the proper channel; cases that have already been decided by a superior authority; ${ }^{168}$ and cases that are not supported by clear facts or sufficient evidence. ${ }^{169}$ In 2013, the CPPLC issued a guiding opinion regarding prevention of wrongful convictions. ${ }^{170}$ At the end of the opinion, Article 15 stipulated that PPLCs shall not coordinate cases of unclear facts and insufficient evidence and that when coordination is justified and conducted, PPLCS shall not provide specific opinions regarding the decisions on the characterization and substantive

\footnotetext{
$162 / d$.

163 Id.

${ }^{164}$ For an overview of some of these wrongful conviction cases, see Margaret K. Lewis, Controlling Abuse to Maintain Control:

The Exclusionary Rule in China, N.Y.U. J. INT'L L. \& PoL. , 668-675 (2010).

165 See Ye, supra note 118. Haoping Qian, zhengfawei zhuanxing zhe yinian [The Year of Transition for Party Political-Legal Committees], NANFANG ZHOUMO [SOUTHERN WEEKEND], Jan. 17. 2014.

166 See Li, supra note 14.

167 See Rules on Party Political-Legal Committees' Supervisory Activities over Law Enforcement Activities of Political-Legal Institutions, supra note 158. Also see Zhongyang zhengfawei ganyu dangwei Zhengfa Weiyuanhui Dui Zhengfa Bumen Zhifa Huodong Jinxing Jiandu De shishi xize [Operational Manual on Party Political-Legal Committees' Supervisory Activities over Law Enforcement Activities of Political-Legal Institutions] issued by Qinghai Province Party Political-Legal Committee in 2012. 168 /d.

${ }^{169}$ Zhonggong Zhangjiagang shi zhengfa weiyuanhui zhifa jiandu gongzuo shishi banfa [Operational Rules on Supervision over Law Enforcement] issued by Zhangjiagang City Party Political-Legal Committee in 2010. Zhonggong huludao shi lianshan quwei zhengfawei zhifa jiandu gongzuo guize [Rules on Supervision over Law Enforcement] issued by Huludao City Lianshan District Party Political-Legal Committee in 2011.

170 Guanyu qieshi fangzhi yuanjia cuoan de guiding [Regulation on Preventing Wrongful Conviction Cases in A Reliably and Effective Manner] issued by the Central Party Political-Legal Committee in 2013.
} 
issues of the case. ${ }^{171}$ In another occasion, Meng Jianzhu, the new director the CPPLC also advised local PPLC leaders not to "send instructions [to judges] regarding decisions on individual cases" so that judicial institutions "can do their job without hindrance". ${ }^{172}$ The SPC capitalized on that momentum and issued an opinion, prohibiting courts from participating in joint-case-handling practices with procuratorates and the police. ${ }^{173}$

However, according to the CPPLC's opinion, PPLCs are prohibited from rendering specific opinions regarding the characterization and substantive issues of cases under coordination only in "normal circumstances". ${ }^{174}$ Presumably, in unspecified "special circumstances", the PPLCs can still send specific instructions to courts regarding whatever issues of the cases that they are coordinating. More importantly, none of the reform efforts mentioned above touches upon the more fundamental issue that has undermined judicial authority and credibility: the issue of the authority of law vis a vis the authority of the party. For example, the current rules are unclear about whether a PPLC can refuse to implement an instruction from a superior party leader to intervene with a case that is not suitable for case-coordination or inspection according to the rules mentioned above.

To summarize, since the party terminated the individual case-approval practice in the 1980s, it has started to conduct its supervision over judicial affairs in a much more selective fashion. On the one hand, the party leaves courts with a measure of autonomy to adjudicate cases of little impact upon the oneparty rule; On the other hand, the party retains its privileged access to and the authority of decisionmaking in cases of its choice. This superior status of the party over courts determines that the party's role in dealing with judicial affairs has two aspects. The first aspect is paternalistic because the party has to provide support to courts to obtain resources and to secure compliance with court decisions by other state institutions that are beyond the reach of courts. The second aspect of the party's role is authoritarian because when the party engages in judicial decision-making its decisions are outcomeoriented, not bound by state legislative procedures and not subject to judicial scrutiny. Specifically, the party engages in judicial decision-making at both the "macro" and "micro" levels. At the "macro" level, the party can make and/or instruct courts to develop judicial policies along the party lines and instructions that will be non-discriminatively applied to all courts and all cases concerned. At the "micro" level, the party has the power to instruct, monitor or scrutinize courts regarding specific decisions of individual cases or categories of cases that attract attention from the party. The "macro" and "micro" approaches are complementary, and the combination of which allows the party to maximize the effect of its control over judicial affairs with limited monitoring resources.

\section{Conclusion}

Compared with what Professor Jerome A. Cohen observed four decades ago, today's political-legal landscape in China is significantly more complex. The party-state is politically more consolidated and

\footnotetext{
${ }^{171} I d$.

172 See Qian, supra note 165.

173 Guanyu jianli jianquan fangfan xingshi yuanjiacuoan gongzuo jizhi de yijian [Opinions on the Establishment and Completing the Operating Mechanism to Prevent Wrongful Convictions] issued by the Supreme People's Court in 2013.

174 See supra note 170.
} 
economically richer and capitalistic; its legal system is more sophisticated and its judiciary more professionalized. However, none of these factors, or their combination, has led the party to embrace judicial independence the same way that Cohen had hoped for in his 1969 article. Instead, the party becomes more assertive in applying its own version of "judicial independence" or "judicial dependence", as demonstrated in this article, where judicial power is divided from other state powers but subjugated to the supreme power of the party.

In this article, I surveyed and examined the relations between the party and courts in three aspects. First, I tracked the institutional changes of the political status of courts in the party-state at different stages of the history of the P.R.C. and explained the nature and implications of "judicial independence" in this particular context. Second, I traced the history of various party institutions that have been assigned to conduct routine inspections of judicial activities since 1949 to the present time. Third, I detailed and analyzed the specific approaches that these party institutions have taken to steer, monitor and scrutinize judicial activities. Based on the findings uncovered in the aforementioned research, I conclude with the following findings.

First, what characterizes the "judicial dependence" in China is that courts are authorized, as specialized state institutions, to apply the law but lack the authority to compel compliance with the law by institutions of equal or higher rank than its own in the power hierarchy defined by the party. This critical feature of China's courts is the direct result of the institutional design of the party-state, under which the party and only the party has the authority to compel compliance by individual state institutions and by the state as a whole. As a result of this particular feature of courts, judicial power becomes susceptible to political power, which is signified by the identities of court-users. It is therefore not surprising that courts can command compliance when dealing with public institutions or officials of lower ranks or with private individuals or entities that have no rank and little capital to draw influence from the former, but cannot command compliance when facing public institutions or officials of equal or higher rank or private individuals or entities that have sufficient capital to draw influence from the former. This finding explains why China's courts frequently demonstrate an almost "schizophrenic" disposition, that it is on the one hand powerful enough to be capable of corrupt conduct when dealing with groups of low or no political power and on the other hand entirely powerless when dealing with groups of significant political power.

Second, denying courts the authority to compel compliance with the law by institutions of equal or higher rank makes the party's involvement in judicial affairs indispensable. From time to time, the party must offer assistance to grant courts the needed resources and authority to compel other state institutions to comply with court decisions and to marshal support and collaboration for courts from institutions and agencies normally beyond the reach of the courts' own authority. This is why the party displays a paternalistic characteristic in its relation with courts, which was persuasively portrayed in Professor ZHU Suli's argument in his various works. However, this article attributes this paternalistic feature of the party to the deliberate institutional design of the party-state, not something that is historically "inescapable". In other words, the paternalistic characteristics that the party has displayed in 
its relation with courts should be understood as a consequence of, not the cause to the party's continued efforts to dominate the state, including courts.

Third, the party controls judicial affairs in two approaches. The first is the "macro" approach, through which the party initiates policies for selected areas of judicial affairs. Such activities allow the party to regulate judicial discretion in a manner that is most convenient for and best adjusted to satisfy its political objectives and priorities. The party also takes the responsibility for "coordination" with other state institutions and for commanding such institutions to cooperate or collaborate with courts in order to ensure the implementation of judicial policies when resistance occurs. The second approach is the "micro" approach, through which the party demands and/or shapes preferred judicial outcomes in selected cases that are of particular interest to the party. The two approaches are complementary: The "macro" approach allows the party to shape general judicial activities on a large scale, whilst the "micro" approach allows the party to overcome implementation pitfalls and to secure intended judicial outcomes in individual cases of particular importance. When the party participates in judicial decisionmaking through either approach, it exercises power in an authoritarian fashion. Its instructions and decisions are not subject to legal reasoning, procedural constraints or appeal, all of which are otherwise required for "proper" judicial decision making. Therefore, no matter how selective and infrequent the party will actually exercise its power and engage in judicial decision-making, its influence upon courts is systematic and structural, the impact of which goes far beyond those "politically sensitive" cases in which the party's footprint is more visible.

\section{List of abbreviations:}

$\begin{array}{ll}\text { CCP } & \text { Chinese Communist Party } \\ \text { CCDI } & \text { Central Party Discipline and Inspection Committee } \\ \text { COD } & \text { Central Party Organizational Department } \\ \text { CPJIR-LSG } & \text { Central Party Judicial Institutional Reform Leading Small Group } \\ \text { CPPCC } & \text { Chinese People's Political Consultative Conference } \\ \text { CPPLC } & \text { Central Party Political-Legal Committee } \\ \text { CPPL-LSG } & \text { Central Party Political-Legal Leading Small Group } \\ \text { KMT } & \text { Kuomintang Party } \\ \text { LPPLC } & \text { Local Party Political-Legal Committee } \\ \text { MOJ } & \text { Ministry of Justice } \\ \text { MPS } & \text { Ministry of Public Security } \\ \text { NPC } & \text { National People's Congress } \\ \text { PPLC } & \text { Party Political-Legal Committee } \\ \text { P.R.C. } & \text { People's Republic of China } \\ \text { SPC } & \text { Supreme People's Court } \\ \text { SPP } & \text { Supreme People's Procuratorate }\end{array}$

